\title{
7 Race (and Reason)
}

Light breaks where no sun shines

Dylan Thomas

In 1937, just before Europe was to explode of its own colliding contradictions, the Trustees of the Carnegie Corporation wrote to a Swedish social scientist, Gunnar Myrdal, to come down to America to study the 'Negro Problem' (sic), objectively and dispassionately (I myself would have chosen subjective and passionate, any time!); and Professor Myrdal, investigation completed, duly wrote a Report, titled The American Dilemma (that ran close to 1500 pages, fully published in 1946); in it, he made the singular observation that the Race Question was an issue at the 'heart' of the average American - implying, in other words, that race, and racism, basically, are moral, not institutional, questions.

This was welcome refreshment, because it is the wonted style of the conventional social scientist to evade moral responsibility and tag 'objective, dispassionate' institutions as the eternal bad guys; and we all know how oh so difficult it is to effect institutional change (which 'social science' is not obliged to seek, qua science, any way). So our conscience is appeased, inexorable external realities are blamed - and nothing ever gets done. Social amelioration is deemed a mystery: we can only wait, and see, and hope.

Americans have largely perceived the omnipresent fact of racism - the unwritten creed of modern Europe - in that general, airy, manner of outright evasion; conventional wisdom has it that 'we all know' it all started with slavery (but in the distant, bad old days), the civil war ended it, the KKK was born soon after trying to restore the Ancien Regime through terror, and then, in the sixties, the good Dr. Martin Luther King came along and helped set right longstanding disabilities, particularly with regard to suffrage. Now, in the ere-present, the fable runs, blacks can vote, they have civil rights, the former army chief-of-staff turned secretary of state under the first administration of King George I was a black man, black athletes clean up big in most sports, and Obama is president now, so what's all the fuss about?

Speaking 'objectively and dispassionately', things are getting better all the time; it's all a matter of evolution and economic growth. Both conservatives and Marxists can now agree: let us get richer, and more prosperous, and the problem will cure itself. When a black is lynched in Idaho (in quite recent memory) for strolling the sidewalk with a white woman, when a Rodney King is brutalized, it can all be explained away as a throwback, as but rude exceptions that prove the rule of progress, improvement, and betterment. What a salve to conscience!; what a sop to the downtrodden!

My liberal colleagues in academe, and in the professions, are all in reconciled agreement with this puerile rubbish; they too, are 'objective and dispassionate', or so they imagine. They have no prejudices, they assure each other, it's all those 
rabid, right wing, rednecks in the 'deep south' (a metaphorical, not a geographical entity, I have discovered, existing everywhere in America), out in the 'boonies' (a New York intellectual, a friend of mine thinks anywhere south of New York is the deep, ignorant, prejudiced, 'south', thus exempting New York, itself a heartland of racial tension, from any such infamy), but definitely someplace else, that keeps the whole sad saga of prejudice and bigotry alive; they themselves do not discriminate - why, they had a black couple over for dinner just the other day; some of their best friends are black, and so on. Of course, they are not lying, at least not all of them, with any seriousness that is; but they are deluding themselves. After all there is no cost to verbal affirmations, to Words that need not be substantiated, to Theory that needs no empirical tests, to fanciful Ideals that nurture one's conscience, and help in getting a good night's sleep; but I have been forty-five years in this country, and I have spent most of it listening, observing and studying; and nowhere in the world is there so much bad faith masquerading as good as in America; nowhere more cant, more hypocrisy, more doublespeak.

The archetypical bigot is not always the sleazy redneck, of popular media fancy, who shotguns the black man in some steamy, Southern backwoods town; it is just as easily us, my cultivated liberal friends (who know at least one black person in their lives, rest assured), the professionals, the elite - who built that gun, oiled it, placed a hairline trigger on it, and gave it to the deliverers, the flunkeys, the peons, to go and do their stuff. When erstwhile candidate Bill Clinton, in fine-tuned opportunism, used a Jackson forum, no less, to turn on Sister Soljah, to secure his White Vote, he was sending the same racist message to the nation's dominant community: I am no 'n-lover', mark you, though I sup with the Reverend Jackson tonight. In that election, at least, the message seemed to have been well received, as expected.

At any rate, the academy, the Temple of Science, is to be entertained with skepticism:they are often the official recorders, the myth-makers, the makers of ideology, dissembling, and disinformation. For a hundred and fifty years, scholars, scriveners, and other sects of learned knaves, from Oxford, England, to Harvard, Cambridge, deceived us into believing that Black Africa could boast of no great civilization, no great proficiency in the arts of civilization, no great feats of art, architecture, nor scholarship to speak of. For a hundred and fifty years, these well-funded sages and savants of the ivory tower, tricked us into believing that Africa and Africans represented, truly, the infancy of humankind, unrefined, uncouth and barbaric - fit only to be ruled, uplifted, and civilized, by white men. Distinguished professors, with endowed chairs, taught us that the Egyptians were white, or at least, not black, not Africans; that Cleopatra was white, that the great civilization of the Nile was a caucasian invention, uncontaminated by black influence. Today, this racist and imperialist myth, invented in the nineteenth century, by the powers getting ready to grab every square mile of African territory (the great Hegel, darling of high German philosophy, lecturing in Jena in 1830, the year France gobbles up Algeria, teaches contented European intellectuals that Africa was no historical part of the world, with no accomplished history, 
no civilizational dynamics, to speak of), is exploded to the high heavens (inspired by the pioneering revealments contained in Onwuka Dike's Thesis of 1956, titled Trade and Politics in the Niger Delta, and buttressed, later, by Martin Bernal's classic Black Athena, published in 1987).

Indeed, Egypt was the product of a black, African, civilization, born long before the Sahara was desert, in the heart of modern-day Sudan. Think of it; Egypt a Black, African, civilization! Classical Greek historians, with no racism in their bones, took no care to hide the fact; and deep was their, generously acknowledged, debt to the Egyptians. Today, Greece is considered the proud fount of western civilization, and yet Greece borrowed heavily from the scholars of Alexandria - indeed a long stint at Alexandria (itself fertilized by the wisdom of India and China) was almost mandatory for philosophers - in every field of inquiry, including astronomy and mathematics. The truth is so startling as to be almost incredible: European civilization, through its Greek mediators, is the undeniable by-product of black Africa.

The architecture of the pyramids, the marvels of Egyptian mathematics and astronomy, were the creations of black Africans; ancient Egypt, the wonder of antiquity, a black civilization. Small wonder racist scholarship found that notion entirely unacceptable, specially in context of their imperial ambitions; so an imaginary caucasian race was invented and planted in black Africa as a European-inspired, masterful, civilizing, influence. There was no end to the fantasizing, to the perfidy, to the distortion; a race of 'Hamites' was invented, caucasoid, naturally, and 'quick-witted', and speaking a 'Hamitic' language, supposedly overrunning, and subduing, the conveniently dim-witted native Africans (the problem runs far deeper, of course; History is written by conquerors - and Europeans, for four hundred years, have written the histories of the world at large: that gives us a measure of just how much needs to be Undone).

So much for the Academy, and its community of 'scholars', run through with every prejudice society is capable of, yet feigning, in recreant unction, 'objectivity, dispassionateness' (I heard a celebrated radical economist, a white American, prominent in New York, hailing from a distinguished American family of economists, tell students that he was 'not yet' emancipated from racism - he was still uncomfortable with blacks, and so forth - but was 'trying hard' to fight against his in-built bigotry, all the same: the craven 'confessional' is yet another popular American feint, guaranteed to secure an easy pardon for all manner of dastardly evasions).

In South Africa, they were straightforwardly racist, and fascist; they despised, hated, and feared, the black man and kept him/her in an animal state of subjugation for decades, White rulers in a black continent, guests that tyrannized over their erstwhile hosts. South Africa was, in recent history, a living museum of white atrocity against the 'Other' peoples of the world, representing, in miniature, the treatment meted out to the non-European world by the European, a stark, but living testimonial to the treachery and brutality of European 'civilization'. South Africa remained a Thorn in the Flesh of Western ideologists seeking to portray four hundred years of colonialism as a great, benign, boon to Asia, Africa and Latin America, instead of the 
wretched, genocidal Tidal Wave of Atrocity it actually was. South Africa was too naked, too exposed, too obvious, too revelatory, for comfort - like Hitler, the regime was frankly racist and reactionary, ideology and practice being in remarkable synch. They were consistent in their barbarism, in their bigotry, in their hatred; they cared not for the gloss of ideology, of cover-up, of fakery, to appease, co-opt, and buy-out, the protest of the lowly (although coaxed ineffectively by the 'enlightened' West for years to adopt a regime of that kind before the deluge of African revolution would drown them - as it did).

Where South Africans made no bones about where they were at, much like our own KKK, we did; we covered up, we pretended, we faked it, to the limits of our very considerable abilities. In public discourse, we preached racial equity, while allowing our deep-seated prejudice to retreat deep into the private sphere where it could live on and be lethal beyond repair. We pretended to be critical of South Africa publicly, much like the British, while privately, and, using both overt and covert channels, invested heavily in it, in both civilian and military sectors, to keep that hellhole of misery alive, well, and on our side. And then, when the tide of black anger within South Africa turned dangerously against the white minority, we started pulling the plugs, scared that if Reforms were not granted soon they might be wrested by force, by the black citizenry, permanently - and that wouldn't do at all.

For years, we assisted the South Africans, militarily, politically, and economically, secretly coordinating deadly strategies against the ex-colonial, and anti-imperial black governments of Angola, Mozambique and Zimbabwe, while issuing routine denials of collaboration with the regime of apartheid. Curiously, we were the bigger hypocrites, liars and perjurers, than the South Africans, who stated their dastardly intentions openly, and fearlessly. And when we did preach to the South Africans, as public necessity sometimes demanded, they would turn to us, with impeccable logic, to say: who are you to preach to us about our Bantustans; where have all your Native Americans gone? And they were right; for the soul of apartheid-Johannesburg lives in America, was born in the U.S.A., is still reared in America, day in and day out. We are racists, period.

The English colonists, pirates and privateers inclusive, entered this continent with the same motives, but with a longer time horizon, of conquest, dispossession and seizure as Columbus did (twelve million hapless tribals perished in the first forty years of the Columbian era), in his despoliation of the Caribbean(Columbus had the gall to claim the New World as his 'discovery', when there were millions already living there; as the leader of the Shawnee Indians put it, recently, the only thing Columbus ever discovered, for sure, was - that he was lost), except they found a much larger continent in which to do it. Europeans fought each other to own North America, a tripartite struggle between Spain, France and Britain, in the main, with Indian tribes used (or attempted to be so used) as pawns in the Great Game.

The great Iroquois (whose principles of Confederation Ben Franklin was to incorporate into the American Constitution), the Sioux, and the Cherokee, among many 
Indian Nations, fought valiantly and lost, falling prey to execrable treachery (gifted blankets, in just one instance, infected with small pox, syphilis), fraud, and chicanery, when not simply to bullets and cavalry charges. Starved of their lands, their hunting grounds, their means of subsistence, the survivors were finally driven out and marched, like cattle, into the human corrals called reservations, where they remain in sullen pride to this day, their treaties violated, their laws disrespected, their cultures desecrated. The white man blew into this Continent like a holocaust; and racism was the fiery Ideology of Expansionism - our very origins, as a nation, besmeared with blood, capsuled with carnage. And, then, the slave trade, the horrific underside, accompaniment of colonization, to European industrialization, growth, and progress; Caribbean sugar, and American cotton, battened on the blood of the African in the so-called triangular trade between Europe, America, and Africa. For two hundred solid years, generations of Africans, human chattel, slaved for their white masters in America and the Caribbean, an estimated two hundred million worked to death, stripped of all human dignities, severed from family and kin, broken by the leash, the collar, the chain, and the whip.

American 'civilization' had a jump start on all the tyrants of this world; even Adolf Hitler trails behind in sheer quantitative comparisons. I remember the oft-quoted reply the soft-spoken Mahatma (Gandhi) gave to the journalist who asked what he thought of 'western civilization', in the throes of Nazism and World-War Two:'I think', he said quietly, 'that it would be a very good idea'. And who, in all good faith, could improve on that comment, even in the twenty-first century?

Like the struggles of the Native Americans, African-Americans have fought back, repeatedly, in a variety of ways; from the 'freedom suits' in the 1770's in the northern states, to the black Jacobin revolts of Gabriel Prosser in Virginia (1800) and Denmark Vesey (1822), to the nationalist manifestos of Robert Young and David Walker (1829), to the back-to-Africa movement of Marcus Garvey (1914), the socialist demands of Philip Randolph (1941); to the black-muslim initiative of Malcolm X, the gun-toting effulgence of the Panthers, and the Gandhian non-violence of King, in the sixties, African-Americans have fought back in almost every way conceivable, politically, militarily, and culturally. Truly, no people have contributed more martyrs, across a longer period of time, to the cause of justice (I remember a talk by a white South African, a Baptist Minister, friendly to the ANC, in which, ruminatively and whimsically, he expressed disbelief at the historical patience of the black people, despite so much abuse: why don't they rise up and kill us all?, he asked, wondering; but they never have - even after victory, content only to get their freedom and get on with their lives with little thought of vengeance and retribution).

More recently, in newly independent Namibia, the sturdy and staid corporate journal, the Economist, was surprised to note that independence from white tyranny still has whites, on average, living seventeen times richer than blacks, and yet with no explicit black backlash of any kind. The simple truth may be unbearable to whites but is the truth nonetheless: there are simply no regimes of black (i.e. reverse) racism. 
And yet, despite all that struggle, sacrifice, and heroism, in America, real amity has never been allowed to prevail between the two peoples. Formal segregations of the two worlds was the rule until very recent history; informal segregation has always been the Law of American Life.

The insidious preference system isolates, separates, and erects barriers that may not be breached - except nominally, hypocritically, ceremonially, and without the slightest degree of good faith; while the media performs sterling, yeoman, service, maintaining time-honored racist stereotypes relentlessly: just observe the depiction of minorities in the run-of-the-mill tv shows. And the ideology percolates everywhere, no sector being immune I remember a foreign student advisor at Columbia University telling me to exercise special care on the Harlem side of the Campus; he meant well, but shared the racial stereotyping of literate, educated America (I had as many chances of being mugged and murdered on the 'white' side of Columbia, as on the 'black' side). It occurred to me that, just possibly, he might be slightly more conspicuous (male, white, wasp) in Harlem than I was (dark-skinned, Indian); but I let the thought go as unworthy. I remember Studs Terkel telling the story, though, of a white woman racing down a Harlem street at night in her car, in a paroxysm of fright, with black men, young and old, waving, deprecating, whistling, cat-calling, even thumping her car at traffic lights, to her unspeakable terror - only to find, once out of the area, and sane again, that she had been driving down a one-way Street, the Wrong way!

We like to imagine that we live in a Plural Society, with multiple traditions, cultures, and orientations (diversity of Cuisines should never be mistaken for diversity of Cultures). We don't; all other Traditions are subject to the sway, the Primacy, of Anglo-Saxon Culture: its politics, its ideology, its laws. Lip service apart, we don't, we couldn't, respect any other tradition (some time ago,the Supreme Court, in its imperious culture-bound majesty, forbade the use of mescaline at Native American religious gatherings) than our own; at most, we give limited rights to other, subaltern, groups to join and participate in the dominant ethos, in our terrain, on our terms. We deploy negative tolerance; there is no open socio-cultural dialogue between the white nation and the black, the hispanic, the Native American, and so on, at any level; it is, instead, a carefully limited, structured, Asymmetrically Closed Discourse, unilaterally setting bounds, rules, and the registry, within which the subordinate, captive, cultures can co-operate with the ruling race, under its guidance, and within its mandate, acceptance of their cultural defeat being the first condition of membership. Our universalism, though high sounding, is spurious, only barely concealing the complete hegemony of European, white civilization.

At a school up East, I had an Ethiopian student, bright, vivacious, popular, and very, very, generous, helping all his classmates prepare for exams; tutoring them, coaching them (sometimes, even writing their Papers for them). An Italian girl, living on campus, was to be completely charmed by his manner, his intelligence, his readiness to help (an Ethiopian assisting an Italian: what historical irony !); his coaching had helped her get through a class she hadn't a hope of passing. Delighted, she called 
home and told her parents about John (for that was his name); her parents, equally happy for her, pressed her to bring John home the very next week-end, and she took him home, in great excitement. The visit didn't last long; one look at John and her parents were horrified; they asked him to leave - at the doorstep, and kept their daughter home; she was to return to school again, only on condition she would never go near John again. That wasn't all; her father called John the next day and threatened him with dire consequences, if he ever 'bothered' his daughter again.

John had the same trouble with his best friend, Jack, an Irish student, a week later; he had prepared some lecture notes for his classmate and offered to drop it off at the latter's home; no, not under any circumstances, came the reply, he could not visit him at home (John was majoring in American studies; he learnt more about America in those two weeks, I warrant, than in all his years at school). Jack, in all irony, was the principal, anti-apartheid, activist on campus organizing teach-ins, sit-ins, on South Africa (and this was in 'liberal' New York, where my 'progressive' friends still think the 'deep south' begins at the very borders of their great state). On Campus, in Theory: liberals, radicals, conservatives - but all dyed in the same wool.

The Rodney King incident only punctured the carefully bandied ideology of America, for being captured on video, and shown on tv; it shocked neither black nor white. Blacks, at the receiving end of far worse than the fate of the hapless Mr. King, for centuries, could hardly affect surprise; the whites, knowing their own dark hearts, could not have batted an eyelid. But the public image was at risk, and the power elite knew it, as they rushed to quiet things down. Bush-I, as President, basically took a law-and-order stance; Clinton, as vote gatherer, even more guardedly, played both sides of it. The problem begun by L.A. policemen was ended by the national guard and federal troops: it's an old routine - and yes, brute force will work every time. At another remove, we have the double tragedy of Hurricane Katrina and New Orleans, where patented racist neglect added the dimension of wholesale disaster to a natural catastrophe. The truth needs be faced head-on: Racism always was, and still is, as American as the fourth of July.

The system is predaciously rotten; and no armada of black Mayors, black Congressmen (or Women), black Businessmen, or black Senators, could make any difference, ever; such institutions assuredly can and do help the economic lot of minorities, but they do not even begin to touch the social, the cultural, and the aesthetic dimensions, where racism is most critically, most viciously, ensconced. A well-fed slave, an employed slave, a well-to-do slave, a suburban dwelling, golf-playing, slave, is still a slave - he knows it, and others know it (the choice between a slave who eats and one who doesn't is a critical one, of course, for the Slave himself/herself; but it's obviously no 'choice' at all); and there can be no peace in that recognition, ever. The regime of Bush II, tokenist to the core, boasted all manner of minorities in it, yet was likely the most openly bigoted regime in recent American history.

In India, there's a caste system that has never really evaporated, despite the hopes, and efforts, of the secular and the progressive; aside from the usual high and 
low castes, there are castes even below the caste line - untouchables, pariahs, whom Gandhi tried to elevate to normal membership of society (India's own brand of colorconsciousness was brought home to me in the unlikely context of a stroll on Broadway, by the theatre district, in New York; a drunk, a black man, sprawled on the sidewalk, suddenly stirred and caught sight of me: 'Oh yeah, you'se Indian, I know,' he yelled, within earshot of five city blocks, 'I know you guys: gotta be white in India, just like here, gotta be white'). But it's never worked; an untouchable may be rich, powerful, may hold high formal rank, it's of little avail - his/her place in the informal ranked order is still at the bottom. There are no simple material olutions - though it's tempting to try them - to issues that are embedded deep in the human psyche by dint of history. Soul searching may not be enough to undo it; but, without it, all other mechanisms must fail.

Another example: in the ex-Soviet Union, women's rights were taken further, constitutionally, legally, and in enforcement, than any western, capitalist democracy. Ivan and Ivana, husband and wife, on average, had broadly equal education, training, and skills; both professionals, working at responsible jobs all day - yet, when they come home, after an equally long working day, Ivan puts on the tv, Ivana switches the stove on : yes, Ivana, it's time to cook. Equal opportunity does not necessarily translate into new cultural definitions of traditional rights, obligations, and responsibilities, whether of gender, race, or caste.

Political and economic remedies are, actually, a far simpler, though far from adequate, answer to issues of cultural oppression. There is, for instance, an obvious national solution to the Race Question in America: Afro-Americans could demand self-determination, their own, independent nation - it would certainly eliminate their cultural degradation in American society (though confirming the perversity of the 'separate, but equal' doctrine, in another way). Equally conceivable, though even less likely, is a multi-racial socialist solution, perhaps, on ex-East European lines, where economic and political disabilities of minorities could be abated, if not abolished - by diktat; although, as with Ivan and Ivana, cultural rankings would probably still not alter much. I knew a famous Polish economist, the late Wlodzimierz Brus, once resident of Oxford, England, who held very high office in Poland, but left, in bitterness, anyhow - because anti-semitism, the age-old blight of Europe, was alive and well, even in the putatively 'Socialist' republic.

It is usually assumed by all manner of reductionists, and rationalists, that racism is about money, about profits, about exploitation (true only at the level of the macrosystem): it has that inescapable dimension, of course, in a commercial society, but there are, at the individual level other, quite independent parameters of prejudice that the materialist thesis ignores to its peril. The typical racist, often, is not one who gains by it, but loses by it. An example: not so long ago, in the Carolinas, Afro-Americans couldn't buy a cup of coffee across counters - the restaurant owner lost custom, not gained, by denying the sale (the Carolinas are desegregated, now, well sort of: I taught at Duke recently and racism was secure even within the august institution). I once 
made a motel reservation by telephone, in the south, only to be turned down when the proprietor saw who I was - he, not I, lost the rental of a room for a night; the boss who prefers a less qualified white to a qualified black, is cumulating losses, not gains.

Similarly, it is assumed that blacks are looked down upon because they were slaves, once upon a time; even more true is the proposition that Africans were enslaved because they were looked down upon. The Irrational is as abundant a part of social life as rationality, materialism and pecuniary calculation; in fact, in my own observation, more so (indeed, the crying weakness of Euro-centered ideology is the denial of the independent role of the irrational in social behavior). This denies the arguments of both (orthodox) Marxists and conservatives, to the contrary; conservatives argue that because racism is irrational ('bosses lose by discrimination'), it will disappear, as the profit motive asserts itself as a liberating force; Euro-centered Marxists argue that a pure capitalism will eliminate these 'throwbacks' to primitive society (so racism in erstwhile S. Africa was seen as the consequence of the primitiveness of South African capitalism, destined to disappear with capital accumulation), as 'progressivist' capitalist advance eliminates these archaic oppressions. Liberals argue that enhancement of legal safeguards, with adequate enforcement, will protect against discrimination. They are all, of course, quite mistaken, in their grasp of the fundamentals of the matter.

Our Swedish Professor, Professor Myrdal, had his finger on the button; apart from all laws, rules, conventions, and practices, which have their own grim reality, unseemly attitudes still fester in our hearts and minds, stoked by propaganda, and fired by ideology. We must know that to even conceive of people, let alone define them, in terms of the accidental characteristics of color, size, or shape, is dire, injurious, maledictory, misanthropy. Black, white, blonde or brunette, are, for all their popular vogue, essentially reactionary social identifications; the term 'black', for instance, is but a mummified concept of 'ethnicity' invented by the dominant white culture to stereotype an entire, diverse people, a bit like men talking about 'women' in a public restroom.

Beginnings need to be humble: before we can travel any further, let us cease to make, and use, such pernicious distinctions - our very language is debased, and debasing, our very concepts a retrograde prison. The racism without, in the external, in the domain of rules and regulations, may well be changed, either by dint of Fear or by the counsels of Expediency: the racism within, is the real nightmare of Americaand it will not let go - it breeds, then builds upon, naked hatred; it thrives upon a savage abhorrence; it is nurtured by a bestial antipathy, detestation, and revulsion. Consider that we dropped two atomic bombs on a nearly prostrate Japan, not white Germany; consider General Westmoreland, co-author of the obscenity of Vietnam, saying, in all seriousness, that Asians do not 'value life' the way we, i.e., white Europeans, do; consider the venomous beating of unarmed Rodney King by a lynch mob of uniformed policemen (another black man was murdered outright by the police in Detroit, only a little after the King affair, during a routine check; it was not caught on 
video, so the nation slumbered on, unstirred: of course, all of this pales before the far more recent outrages in Ferguson and Baltimore); consider the reservations we have doomed Native Americans to, the Bantustan-ghettos that our fellow citizens, blacks and hispanics inhabit, the US-born Japanese we interned in camps with barbed wire fences in World War II, the forced sterilizations of welfare blacks, the human rights we have denied, right here at home, while preaching piety to the communist world; consider all these, and more.

Long before we fabricate social constructions, the barbed wire is erected in our minds, in our hearts, in our imaginations. But hearts and minds can be changed, cleansed, revitalized; but only on the basis of an alteration in those fundamental values - unbounded lust, greed, and conquest - that have spurred European civilization for four hundred years, powering its relentless expansion into every corner of the globe.

Racism and sexism are not far apart; indeed, in the American psyche they bear close kindred. White patriarchy has always seen white women as the sole preserve of the white man, not to be 'violated' by the inferior races; British policy in the colonies was quite candidly explicit (a main theme in the somewhat sordid Jewel in the Crown series, run by British television some years ago); any sexual relations between white women and non-white men was, automatically, rape - carrying, usually, the ultimate penalty. No such stipulation attached, naturally, to white men having relations with non-white women, white men claiming rights to 'property', in women, amongst both whites and non-whites.

And the alleged sexual prowess of non-white men, blacks particularly, made the taboo even more fierce - John, my Ethiopian student, was therefore treading on an old, well-secured, tripwire, without knowing it. The need to socially barricade blacks against normal societal contacts with whites stems from this deep, in-built insecurity of white patriarchy (laws against 'miscegenation', a word but only recently lapsed from the lexicon of general Anglo-Saxon usage, still sit untouched in the statute books in several states). In the sixties, the decade of world revolution, protest and civil rights struggles in America, Hollywood capitalized on this issue with their slick, soppy, and sugary, film, 'Guess who's Coming to Dinner', featuring big name stars, and designed to play on the heartstrings. The theme was simple, a black man and a white woman wanting to marry each other, but that was all; and I can't think of even half a dozen films in the history of Hollywood, let alone television, that dared to broach such themes in a normal, non-dramatic, undidactic way.

White men and black women, Yes: black men and white women - No ! Indeed, a representative of the Aryan Nation explicitly made reference, on national tv, to the consequences likely to befall black men attempting to befriend white women (something black men need little education in, you'd have thought, given their long experience of white hatred); this, at about the same time that the political maverick, David Duke, KKK in his convictions, was making a presidential bid from the 'deep south'. To think of these as 'fringe' attitudes is to seriously mistake appearance for essence. 
The fringe itself is an interesting concept, with a latent political function. I remember the hoary era of Enoch Powell, in England, the racist demagogue who wanted an All-white Britain, free of all minorities, Indians, Pakistanis, West Indians, etc. (I also remember a sari-clad Indian woman who marched in London, in response, with a placard that read, simply, 'We are here, because you were there'), who were imported, virtually as coolie labor, by cynical British economic policy, decades earlier, to break the strength of British unions, lower the wage rate, and perform work below the dignity of the Anglo-Saxon. I also remember Mr. Powell as the man who had the guts to say things the Tories just stopped short of saying, in public; of course, Mr. Powell was only articulating widely and deeply held beliefs (the fact that even Eric Clapton is said to have endorsed the National Front, at one point, suggests that Mr. Powell was not that far removed from the thin conscience of white Britain) - indeed I myself had heard worse things said to me by educated, liberal, intellectuals in Britain - and his inflammatory rhetoric helped increase the climate of terror under which minorities lived, encouraging the pastime of 'Pakky-bashing' (beating up on Asian immigrants), putting pressure on many to reconsider their British exile.

While ritually pooh-poohing Mr. Powell, the Tories could have their Conservative cake and eat it too; he did their nasty work for them, without upsetting their image as a clean, non-racist party. Whether a Pen in France, a Powell in Britain, or a Duke in America, the racist fringe exists at the pleasure, if not at the behest, of the dominant powers; it enables them to achieve their ends, without the guilt of exposure. In our metaphorical 'deep south', the difference between a Klansman and a uniformed policeman may rest only in the degree of legality attaching to their actions vis a vis the black community. Racism is not a fringe phenomenon; it lives at our very roots, at the epicenter of our political economy.

There are no simple eco-political solutions to enduring cultural oppressions; and both liberals and the Marxists err profoundly in this regard with their facile reductionism, and their simpliste social agendas. The truth is that, rhetoric to the contrary apart, no amount of affluence, or economic growth, will, all by its mechanical self, eliminate racial feelings in the U.S., nor caste-consciousness in India, precisely because such sentiments are sentiments, primarily. Of course, an astute capitalist political economy, in conjunction with racial polices, has succeeded in keeping freed slaves as a permanent, necessary under-class in American society; but, even a suddenly 'socialist', or 'communitarian' America (absurd as that sounds in this neo-liberal twenty-first century) could hardly be relied upon to improve their cultural ranking, which would probably remain on par, rather akin to the situation of the Jewish community in the brief tenure of 'socialist' Poland just described.

So to dream of such final, tomorrow's Revolutions as cures to such maladies is, quite often, but a means to disclaim all current responsibility, in utterly reactionary passivity, to affect cultural change, in the name of some apocalyptic future redemption; and, for generations, such myths have only assisted in consecrating the bad faith of many a card-carrying radical. Racial sentiment is not primarily constituted at 
the level of a nation-state; and so, much like gender oppression, it cannot be fought, let alone be prevailed upon, at that exalted level alone. The state is not about sentiment: but, is concerned, rather, with rational domination.

The lofty, high-minded, charters of liberation come and go, churned in the historical maelstrom of the running dialectic of rule and resistance, but the verities of oppression seem to go on forever. As sentient individuals, we can do a whole lot more than merely embrace the chimera of the nearest docket of political salvation, if only in the sphere of our private lives, and try to extirpate, at the very base of our consciousness, the deep-rooted dualisms of all of our divisive ideologies - race, class, gender etc.- that keep us in thrall, permanently bogged down in bitter struggle, conflict, and competition, with others - seeking instead, in all pacific inspiration, the inclusive unity of life in all its variety, diversity, and infinite texturing.

Nelson Mandela captured the Gandhian essence of this in his sagacious Project of 'national reconciliation', after the liberation of South Africa, and it serves as a template worthy of emulation. We will not reverse, thereby, in any sudden, abrupt act of restitution, all of the received tragedies of history: but we would have taken a first, human step in the long, and arduous, road to a kind, caring, clement, and commiserating, reparation. Now that all the other ways seem to have been tried, it is perhaps time we built our soaring Utopias, henceforth, from the inside out. 